\author{
Ewa Woźniak, Magdalena Gozdek \\ Uniwersytet Łódzki
}

\title{
Jakim językiem XVI-wieczni pisarze reformacyjni pisali o wychowaniu dzieci (Gliczner, Kwiatkowski, Lorichius)?
}

Autorzy, których język uczyniłyśmy przedmiotem naszego zainteresowania, należą do mniej znanych pisarzy doby odrodzenia. Rozpoczniemy zatem od ich krótkiej prezentacji, koncentrując się na tych aspektach, które są istotne z punktu widzenia podjętego zagadnienia, a więc na ich związkach z reformacją oraz twórczości o tematyce pedagogicznej.

Erazm Gliczner rozpoczął działalność pisarską od traktatu Kfyafzki o wychowányu dzyeći bárzo dobre, pożyteczne, y potrzebne, s których rodzicy ku wychowányu dzyeći fwych, náukę dołożna wyczerpnać mogą. Teraz nowo uczynione y s pilnofcia wyrobione. W Krákowie, drukowano przez Mattheufzá Syebeneicherá Roku Pańfkiego. M.D.L viij. W roku wydania tej książki Gliczner miał 23 lata, a więc - jak pisze Antoni Danysz - ,,co dopiero był wyszedł z wieku wychowawczego i do napisania książki pedagogicznej był o wiele za młodym" [Danysz 1912: 7-8]. Być może ze względu na młody wiek i brak autorytetu autora publikacja nie zyskała popularności, o czym może świadczyć zaledwie jeden zachowany do dziś egzemplarz starodruku: jest on własnością Biblioteki Zakładu Narodowego im. Ossolińskich, udostępniony w postaci skanów w Dolnośląskiej Bibliotece Cyfrowej. Ten unikatowy egzemplarz przetrwał zapewne dzięeki bibliofilskim kwerendom Samuela Bogumiła Lindego, który wykorzystał go jako źródło w swoim słowniku. Jako autor Ksiązek o wychowaniu dzieci Gliczner zyskał miano ,pierwszego polskiego pedagoga” [Ottmann 1886: 441]. Dowody na jego związki z reformacją mamy dopiero z roku 1560 (a więc już po wydaniu Książek...). Można przypuszczać, że w kształtowaniu poglądów religijnych Glicznera znaczącą rolę odegrała edukacja w humanistyczno-protestanckiej szkole Walentego Friedlanda Trotzendorffa w Złotogórze. Jednak w 1558 roku jego nazwisko figuruje jeszcze w spisie studentów 
uniwersytetu w Krakowie, do którego wstęp wymagał złożenia deklaracji wierności wierze katolickiej; dopiero później w metryce uniwersyteckiej dopisano przy jego nazwisku Lutheranus [Danysz 1912: 7] ${ }^{1}$. Od początku lat 60. XVI wieku Gliczner aktywnie działał w środowisku wielkopolskich luteranów, a w 1566 roku został mianowany pierwszym superintendentem Kościołów protestanckich w Wielkopolsce [Pollak 1964: 193]. Pełniąc powierzoną funkcję, starał się o porozumienie z innymi wyznaniami protestanckimi. Przykład stanowić mogą kilkukrotne nieudane próby zwołania synodu generalnego [Bidlo 1977: 170-171]. Był jednym z twórców tzw. zgody sandomierskiej [Sławiński 2003: 9-71]. Pod koniec 1594 roku wydał własny przekład Konfesji augsburskiej [Sławiński 2003: 59-60]. Przez historyków uznawany jest za osobę zasłużoną dla polskiego protestantyzmu.

Książki o wychowaniu dzieci to oryginalne dokonanie Glicznera. Inspirację do jego stworzenia dał zapewne udział w przygotowaniu do druku trzeciego wydania polskiego przekładu dzieła pedagogicznego niemieckiego teologa protestanckiego Reinharda Lorichiusa (1500-1564). Glicznera zaangażował do prac nad edycją tłumacz, Stanisław Koszutski. Autorski wkład Glicznera w tę publikację polegał na napisaniu wiersza Na herb iego Miłości Kxiążęcia Stuczkiego, listu dedykacyjnego do Mikołaja Trzebuchowskiego oraz przełożenia dołączonej do dzieła Oracji o sprawowaniu państwa Isokratesa.

Dzieło, o którym mowa, a więc Reinharda Lorichiufa kxięgi, o wychowaniu y o czwicżeniu káżdego przetożonego, nie tylko pánu ale y poddánemu każdemu ku cżytániu bárzo pożytecżne: teraz nowo z táćińfkiego ięzyká ná polfki przetożone, w przeciwieństwie do oryginalnej książki Glicznera, musiało cieszyć się w swoich czasach dużym zainteresowaniem. Świadczą o tym trzy wydania: pierwsze w $1553 \mathrm{roku}^{2}$ i drugie w 1555 w Wilnie [Kraszewski 1842: 116], trzecie - to, przy którym współpracował Gliczner, w Krakowie w 1558 roku „u dziedziczow Márká Szárffenbergerá”. W zbiorach bibliotecznych zacho-

1 „Kiedy znakomite dzieło Książki o wychowaniu w r. 1558 w Krakowie wydawał, Lutrem być nie mógł, wydawnictwo bowiem przypada na ten sam rok, w którym na Uniwersytet Jagielloński uczęszczał, a jako uczeń składał przysięgę, iż stoi i stać będzie przy wierze katolickiej” [Ottmann 1886: 448]. Według Henryka Barycza Gliczner wpisał się w poczet studentów Uniwersytetu Jagiellońskiego, aby zapewnić sobie wsparcie uczelni w procesie z wydawcą Mikołajem Szarfenbergiem: „on, uczeń Goldbergu i Królewca wpisał się w poczet uczniów Akademii Krakowskiej w półroczu letniem 1558 r. (właśnie w chwili toczenia się procesu). W ten tylko sposób tłumaczę sobie [...] jego immatrykulację w Krakowie, do którego zjechał przecież nie na studia, lecz w celach wydawniczych" [Barycz 1924: 300].

2 Był to pierwszy druk wileński przetłumaczony z łaciny na język polski [Znajomski 2015: 45]. 
wało się kilka egzemplarzy tej ostatniej edycji, a mimo to wśród badaczy zajmujących się współcześnie historią wychowania czy edukacji jest to dzieło mało znane. Dość wspomnieć, że autorka publikacji Ideały edukacyjne doby staropolskiej. Stanowe modele i potrzeby edukacyjne szesnastego i siedemnastego wieku go nie cytuje ${ }^{3}$ [Żołądź 1990], natomiast w artykule Filologiczna edukacja i szkolnictwo humanistyczne w XVI i XVII wieku w Polsce błędnie podano, że księgi Lorichiusa przetłumaczył na język polski Erazm Gliczner [Piskała 2011: 245$]^{4}$. Tymczasem thumaczem dzieła był, jak już wspomniano, Stanisław Koszutski (zm. 1559). Pochodził z Wielkopolski, a związany był najpierw z dworem Mikołaja Radziwiłła Rudego, a później Barbary Radziwiłłówny i Zygmunta Augusta.

Środowisko protestanckie reprezentuje również Marcin Kwiatkowski, autor rozprawki Xiążecżki rofzkofzne á wielmi użytecżne o poććiwym wychowaniu y w rozmáitych wyzwolonich naukach cżwicżeniu Krolewskich, Xiążecych, flacheczkich, y infzich ftanow dziatek, do Ubertina ná ten cżás Xiażęćia Padewskiego Łaczinskim iężykiem napifane. A teras z wielka pilnośćia á praca z Łaćińskiego na Polfki, przes MARCINA QWIATKOWSKIEGO Z ROZYCZ ná ten cżás X.J.M. Prufkiego, etc. etc. Iorgieltnika przełożone, y nakłádem ubogim wydrukowáne. Roku Pańskiego. 1564. Dziełko to było tłumaczeniem traktatu włoskiego humanisty Piotra Pawła Vergeria Starszego De ingenuis moribus ac liberalibus studiis, żyjącego na przełomie XIV i XV wieku (1370-1444). O samym Kwiatkowskim wiemy niewiele. $Z$ informacji, jakie zawarł w jednej ze swoich publikacji, wynika, że pochodził z Różyc, a jego ojcem był Albert (Wojciech) Lutomirski [Pawlak 1997a: VII]. Można podejrzewać, że pierwszy kontakt Kwiatkowskiego z doktryną reformacyjną miał miejsce w domu Lutomirskich, w którym się wychowywał [Pawlak 1997a: VIII]. Dzięki pomocy finansowej, jaką otrzymał od swoich opiekunów i księcia Albrechta, mógł studiować na uniwersytecie w Królewcu. Wiosną 1561 roku Kwiatkowski, podobnie jak później Gliczner, dokonał przekładu Konfesji augsburskiej na język polski. W tym samym roku rozpoczął pracę na dworze książęcym, gdzie zajmował się głównie tłumaczeniem polskich listów na język łaciński i niemiecki. Sprawował również opiekę nad synem Mikołaja Reja [Pawlak 1997a:

3 Autorka cytuje jedynie fragment z Dedykacji do ksiąg Lorichiusa, napisanej przez tłumacza, Stanisława Koszutskiego, za opracowaniem Witolda Taszyckiego Obrońcy języka polskiego. Wiek XV-XVII, Wrocław 1953 [Żołądź 1990: 32].

4 W literaturze przedmiotu znaleźć można jeszcze więcej nieścisłości. Na przykład z informacji o powstaniu przekładu ksiąg Lorichiusa, podanej w artykule poświęconym poglądom pedagogicznym Lorichiusa i Koszutskiego, wnosić można, że było tylko jedno wydanie tej książki, w Krakowie w 1558 roku [Pawlak 1996b: 189]. 
IX-XIII]. Kilka lat po wydaniu Ksiązeczek rozkosznych ukazało się, tym razem po łacinie, kolejne dziełko pedagogiczne Marcina Kwiatkowskiego - Libellus fere aureus... (Książeczka niemal zlota...) [Pawlak 1997a: XXV-XXVI].

Celem artykułu jest przedstawienie wybranych właściwości stylistycznych książek o wychowaniu dzieci, powstałych w środowisku protestanckim w Polsce w XVI wieku. Dodatkowo pytamy też o wpływ preferencji wyznaniowych na językowo-stylistyczny kształt publikacji. Omawiane utwory znacznie różnią się długością: najobszerniejsze jest dzieło Lorichiusa, liczące 186 kart, Książki... Glicznera składają się z 16 kart dzielonych na osiem składek, co daje ok. $238^{5}$ stron małego formatu, najkrótsza jest rozprawka Kwiatkowskiego licząca 16 kart dzielonych na cztery składki, czyli ok. 125 stron (we współczesnym wydaniu ma niecałe 70 stron). Już choćby to jest powodem różnic językowo-stylistycznych. Poza tym łaciński oryginał dzieła Kwiatkowskiego pochodzi z początku XV wieku (ok. 1400), utwory Lorichiusa i Glicznera wyrastają już z innego podłoża umysłowego. Mimo to u omawianych trzech autorów starałyśmy się wskazać cechy wspólne. Za stylistyczne dominanty ich dzieł uznałyśmy dydaktyzm, obrazowość i erudycyjność. Za Teresą Skubalanką te stylistyczne dominanty nazywamy również kategoriami stylistycznymi, przyjmując, że są to wiązki cech charakterystycznych, a ściślej - skupienie składników języka będących nośnikami tych cech [Skubalanka 1997: 150] .

\section{Dydaktyzm}

Autorom przyświeca cel dydaktyczny: ukształtowanie poglądów dotyczących wychowania dzieci. Oczywiście pisarzom leżało na sercu nie wychowanie dzieci w ogóle, ale opieka nad potomkami wysokich rodów czy rodzin szlacheckich oraz ich kształcenie, przygotowanie do pełnienia w przyszłości ról właściwych dla wyższych stanów społecznych. XVI-wieczna twórczość o tematyce pedagogicznej nie miała charakteru demokratycznego. Reinhold Lorichius adresował swoje wskazówki do wychowawców przyszłych przełożonych, oryginał Książeczek rozkosznych Kwiatkowskiego był napisany

5 We wszystkich publikacjach zastosowana została charakterystyczna dla XVI wieku numeracja stron za pomocą liter alfabetu oraz cyfr: arabskich u Lorichiusa i Kwiatkowskiego, rzymskich u Glicznera. Oznaczenia stron umieszczone zostały pod tekstem właściwym na stronach nieparzystych.

6 „Kategorią stylistyczną nazywam skupienie cech charakterystycznych, inaczej mówiąc skupienie składników języka, będących nośnikami wspomnianych cech. [...] kategoria stylistyczna jako taka wskazuje na obecność wybranych składników stylu i ich funkcje" [Skubalanka 1997: 150]. 
w formie listu do księcia padewskiego Ubertyna, natomiast Gliczner kierował zalecenia do obdarzonych potomstwem przedstawicieli warstwy szlacheckiej.

Wykładnikiem dydaktyzmu są egzempla, którymi autorzy ilustrują propagowane poglądy oraz je potwierdzają. Przykłady unaoczniają stawiane tezy, służą lepszemu ich zrozumieniu, a także je utrwalają. Wyjątkowa obfitość egzemplifikacji charakteryzuje zwłaszcza dzieła Glicznera i Lorichiusa, Kwiatkowski jest pod tym względem oszczędniejszy (co oczywiście wynika z różnej obszerności wywodów). Przykładów dostarczają przede wszystkim mitologia oraz historia i filozofia starożytna, a Glicznerowi i Lorichiusowi również Biblia. Autorzy nie odbiegają tu od zwyczajów epoki. Kwiatkowski preferuje przykłady z historii Rzymu, co z kolei wiąże się z adresatem, do którego kierowany był oryginał książki; przywołuje również wzory przodków księcia Ubertyna. Dowodzenie tezy nie kończy się na jednym przykładzie. Egzempla są kumulowane, a wnioski z nich wynikające za każdym razem powtarzane są innymi słowami. W ten sposób realizuje się zasadę utrwalania przez repetitio oraz wykorzystuje jeden z bardziej cenionych wówczas środków stylistycznych - copia verborum. Interpretacja, wyjaśnienie przykładu wprowadzane jest wyrażeniami metatekstowymi, bardzo różnorodnymi, często zawierającymi językowe wykładniki oczywistości sądu, blokujące weryfikację, czy też kwantyfikatory uogólniające, podkreślające bezwyjątkowość, jak np. każdy: „z ktorych flow może to káżdy uiąć” [G Biij], „cżego dokłádáyą ty flowá”; „ktoremi flowy okazał to po fobye pan bog”; „ná oko thu widzimy” [G Biij] „co też y s tego poznáć możem” [G Biiij $]$ ], ,ale nye telko the przykłády zá naffą rzecżą ftoyą, ktorą powyadamy [...]. Możem też y inffymi tego dołożyć" [G Biiij $]$ ], „Ten przykład naucżyć może rodzice” [G Fvij], „widzim to fami ná oko” [G Fvij $]$ ], „Co ftego łatwye poyąć możem, bárzo” [G G], „Ten przykład okázuie” [G Gij], „iako otym fama rzecż pokazuie” [K L], „Abowiem co na oko widzimy y uftawicżnie tego doświatczamy” [K M2], „Czo mowiącz o tym ro[z]umiał, iż” [L B2 ] ], „Ztąd obacżyć możemy żeć” [L B2 $2_{\mathrm{v}}$ ].

Z przykładów oraz ich eksplikacji wynikają zalecenia:

Dla cżego [z tego powodu] dobry pan káżdy, wffelákiey fye fpráwy z białemi głowámi, abo z głádkiemi đlużebnemi pánienkámi ma wiárowáć, á ma fye Itrzec $^{7}$ y tych nierządnic ktore dwor bárzo miłuią $[\ldots]\left[\mathrm{L} \mathrm{M}_{\mathrm{v}}\right]$

Thák fye tedy pan káżdy ma ftrzec rozmow obłudnych, káżdey nierządnice, iáko fye ftrzegł on flawny Grek Ulifes tychto Syrenes $\left[\mathrm{L} \mathrm{M}_{\mathrm{v}}\right]$

7 To i dalsze wyróżnienia oraz dopowiedzenia w cytatach pochodzą od autorek artykułu. 
Maią tedy być naucżani młodzieńcżykowie [...], yżeby mogli nieprziaćiela kordem prawą ręką ćiąć, á lewą fię bechterzem álbo puchlerzem zakrywać y záftáwiać $[\ldots]$. [ $\left.\mathrm{K} \mathrm{O}_{\mathrm{v}}\right]$

Przejawem dydaktyzmu jest nie tylko interpretujący komentarz, wyjaśniający, o czym świadczy przedstawiony przykład i jaka dyrektywa dotycząca postępowania z niego wynika, ale również wybiórczość w zakresie przekazywanych treści. Widać to na przykładzie historii biblijnych, które autorzy przekształcają tak, aby dobrze ilustrowały udowadnianą tezę. Modyfikacja może polegać na pomijaniu treści niepasujących do dowodu. Przykładem jest sposób prezentacji losów dwóch synów Abrahama: nieślubnego Izmaela i z prawego łoża Izaaka, które Gliczner przywołuje, żeby potwierdzić tezę o słusznej dyskryminacji dzieci pozamałżeńskich, co z kolei jest mu potrzebne, żeby dowieść szkodliwości stosunków pozamałżeńskich w rozdziale Yáko fzkodliwa rzecż yeft oycowi z nieforemna, á podeyrzána byała głowa myeć dzyeći [G B]. Autor Książek..., podając w mowie niezależnej słowa Boga skierowane do Abrahama, a zachęcające do pozbycia się Izmaela i Hagar zgodnie z wolą Sary, pomija obietnicę rozmnożenia również potomstwa Izmaela. Poniżej przytaczamy dłuższy cytat, ponieważ dobrze ilustruje on stylistyczne ukształtowanie tekstu w służbie dydaktyzmu. Wyróżnione zostały fragmenty zawierające wyrażenia metatekstowe wprowadzające interpretujący komentarz:

[...] fam pan Bog rzekł ku nyemu: Nye obawyay fye Abráámie tego ucżynić, ále wtem wffytkim bądź powolny żenye twey. Abowim nie Izmáel, ále Izáák włafny fyn będzye ucżefnikyem obyetnice, kthoram ya o rozmnożeniu narodu tobie wydał. $\mathbf{Z}$ ktorych llow może to káżdy uiąć, iż nye telko thu ná tym fwyecye nyepráwi fynowye w zgárdzye, á w podłem popifye są. Ale theż y Bog fam nyeradby áby fye rodzili, cżego dokłádáyą ty flowá, gdy mowi: Nye żáłuy áni Izmaelá áni mátki yego, y owflem cżyń to co ieft wola włafney żony twey. Abowyemći Izáák á nye Izmáel będzye dzyedzicżył, y od nyego fye pocżnye rozmnożenye potomftwá á narodu twego, iakoby rzekl, nyepewnać to áby kyedy Bękártowye myeli dzyedzicżyć [...]. Iż thedy nye po mey woli fye to ftáło, żes ty używal dzyewki rzędney dla płodu, ten też płod nye będzye miał nic z obietnicą moią, ktoramći dał o rozmnożeniu narodu twego [...]. Ktoremi flowy okazal to po fobie pan bog że nyechce tego áby fye kyedy ludzye okrom małżeńltwá rodzili. Ná oko thu widzimy że dzyeli y wyłącża płod nyewłafney żony Hágár, od płodu włafney żony. Yáko cżynią páftuchowye w oborze około fkotu y bydłá, dobre á zdrowe owce od párflywych á záráźliwych przefadzáyą, aby fye nye myęlláły, sámy od fyebye nye káźiły. [G Biij-Biiij] 
Wersja oryginału (według Biblii Leopolity) brzmi następująco:

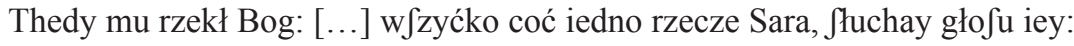
Boć w Izááku będzie tobie wezwano nasienie. Aleć y fyná fłużebnice rozkrzewię w narod wielki, ábowiem náfienie twoie iefth. [Biblia Leopolity, Rdz $21,12-14]$

W przytoczonym fragmencie Ksiażek o wychowaniu dzieci wypowiedziana przez Boga zachęta, by Abraham oddalił Izmaela, dwukrotnie podana w formie oratio recta, za każdym razem otrzymała odmienny kształt leksykalno-składniowy. Powtarzanie tej samej treści innymi słowami należało do cenionych wówczas środków stylistycznych, służących jej uwydatnianiu i utrwalaniu. Negatywną ocenę potomstwa pozamałżeńskiego, również kilkukrotnie powtórzoną, obudowuje autor operatorami metatekstowymi o funkcji utożsamiającej, wskazującymi na znaczeniową ekwiwalencję pomiędzy tą oceną a słowami Boga przeciwstawiającymi „własnego syna” Izaaka Izmaelowi: $z$ których słów może to każdy ująć...; czego dokładaja ty stowa, gdy mówi...; jakoby rzekt; Ktoremi stowy okazat to po sobie Pan Bóg, że... Ostatni z operatorów dzięki użyciu czasownika w 1 . os. $1 \mathrm{~m}$. widzimy oraz potocznego na oko uaktywnia kontakt z odbiorcą: na oko tu widzimy, że... Kontynuacją tego zejścia na bliższy odbiorcy poziom potoczności jest również obrazowe porównanie, odwołujące się do doświadczeń związanych z hodowlą bydła.

Dydaktyzm realizuje się przez przybliżanie odbiorcy trudnych znaczeń. Widać to na przykładzie wielorako wykorzystywanych odwołań do Biblii. Autorzy korzystający z tego źródła, a więc Lorichius i Gliczner, nie tylko trawestują historie biblijne (w różny sposób je przekształcając), ale również przytaczają fragmenty o charakterze sentencjonalnym, np. z psalmów, ksiąg mądrościowych czy ewangelii. Cytaty te zapowiadają wyrażenia: „nie dármo nápifano" [L M3], ,według flow Duchá S.” [ $\left.\mathrm{G} \mathrm{C}_{\mathrm{v}}\right]$, ,według flowá páńlkyego” [G D], ,według Sálomoná” [G D], ,rzecż, ktorą cżynił pan Kriftu [...], mowyąc” [G Diij], „Pan Kriftus powyedzyeć racżył” [G Dvij], „yako fam [Pan Bóg] obwyesćic to racżył temi flowy” [G Dvij $]$ ], ,yáko cżytamy w Biblij” [G Dviij] ]. Niekiedy lokalizacja cytatu podawana jest na marginesie (często u Lorichiusa). Jeśliby porównać zbliżone czasowo przekłady odpowiednich fragmentów Biblii z obecnymi w dziełach przywoływanych autorów, to zwraca uwagę ich staranie o oddanie nie tyle litery, ile sensu. Ilustrują to następujące przykłady:

a) z Reinharda Lorichiusa Ksiag o wychowaniu w przekładzie Koszutskiego cytat z Księgi Przysłów oraz dwóch najbliższych im czasowo (późniejszych) thumaczeń - Biblii Leopolity (1561) i Biblii brzeskiej (1563): 
Abowiem uftá nierządnicze gládkiey, fą iáko pełny pláftr miodu, á fzyiá iey miękcżeyffa niż oley, ale fkutek ná oftátku iefth ták gorzki iáko piołyn, ták oftry iáko miecż, nogi iey ku fmierći przychodzą, á fzćie iey do piekłá fye pośpieffa. [ $\left[\mathrm{L} \mathrm{M} 2_{\mathrm{v}}\right]$

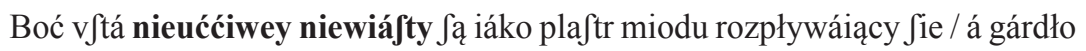

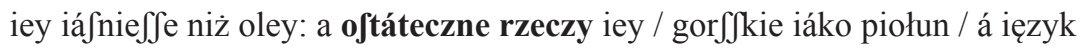
iey oftry iákoby miecz oboiętny. Nogi iey z Jtępuią ná Jmierć / á kroki iey przenikaią aż do piekłá. [Biblia Leopolity, Prz 5,3-5]

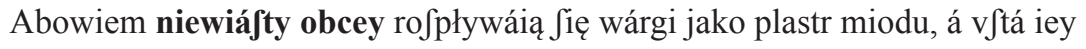

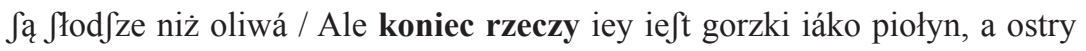
iako miecz po obu Jtron oftrze máiący. / Nogi iey zJtępuią do śmierći, á chod iey ćiągnie Jię do piekłá. [Biblia brzeska, Prz 5,3-5]

b) z Książek o wychowaniu dzieci Glicznera, w porównaniu z przekładem Leopolity i brzeskim:

O cżym Duch s. mowi ták do nas przez Proroka: Dziatek ofyadłosć od Bogá yeft, á płod żywotá, miáfto zapłáty dawa pan Bog. Yákye fą ftrzały w rękach dużego cżłowyeká, tákye fą dzyatki, ffcżęlliwi tho rodzicy, ktorzy tákowych ftrzał mayą dofić w fáydaku, abowyem oni nye omylą fie áni uftáną, gdy będą myeć potrzebę z nyeprziyacyoły fwemi. $\left[\mathrm{G} \mathrm{CV}_{\mathrm{v}}\right]$

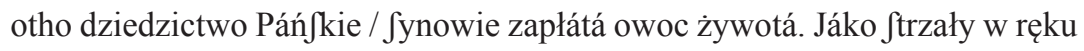

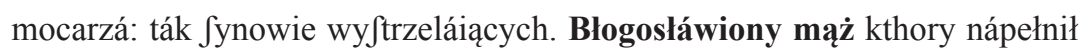
żądość $\int w a ̨$ z tych: niebędą zelżeni gdy będą máwiáć nieprzyiáćielom $\int w o i m$ w branie. [Biblia Leopolity, Ps 126,4-6]

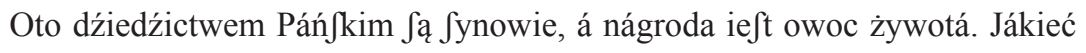

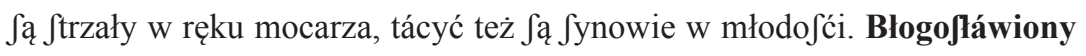
ten czlowiek iest, ktory nápełni sáháydák $\int w o y$ imi, ábowiem nie będą zaw ftydzeni, gdy będą mieć Jpráwę w branie z nieprzyiaćioły Jwemi. [Biblia brzeska, Ps 127,3-5]

Tłumaczenia z dzieł Lorichiusa-Koszutskiego oraz Glicznera pozbawione są biblizmów stylistycznych (błogosławiony mąż, niewiasta obca, ostateczne rzeczy, zstepować na śmierć / do śmierci, kroki przenikaja), których obecność w polskojęzycznych Bibliach jest wynikiem stosowania werbalnej metody 
przekładu. Zastępuje się je wyrażeniami bardziej pasującymi do kontekstu, np. szczęśliwi rodzicy, nierzadnica gładka, i naturalniej brzmiącymi w polszczyźnie, np. skutek na ostatku czy nogi przychodza, szcie sie pospiesza, które nie odwzorowują obcojęzycznego pierwowzoru. W przekładzie Glicznera zamiast typowo biblijnego wyrażenia błogosławiony mąz mamy bardziej adekwatne, bo nazywające relacje rodzinne: szczęśliwi rodzicy. Warto zauważyć, że konsekwencją tej zmiany jest odejście od obecnego w tekście biblijnym obrazu patriarchalnego: potomstwo zostaje przedstawione jako dobrodziejstwo dla obojga rodziców, nie tylko dla mężczyzny. Semantycznie ważne jest również przesunięcie na pozycję inicjalną w dwóch paralelnych członach wyrażeń odnoszących się do (posiadania) dzieci, a więc: dziatek osiadtość i płód żywota. $\mathrm{W}$ ten sposób to dzieci, ich posiadanie stają się tematem wypowiedzi. Przyjęta perspektywa eksponuje nie dawcę, a więc Boga, ale dar, jakim są dzieci. Inaczej rozłożone są akcenty w wersji z Biblii Leopolity oraz Biblii brzeskiej, w których w części tematycznej analogicznych członów mamy: dziedzictwem Pańskim oraz nagroda / zapłata (w domyśle: dana przez Boga) - na plan pierwszy wysunięty zostaje Bóg jako dawca potomstwa.

Na podstawie przedstawionych przykładów można stwierdzić, że stylistyczne ukształtowanie badanych tekstów podporządkowane jest celowi dydaktycznemu. Najważniejsze tezy są powtarzane, przy czym wykorzystuje się różne środki dla wyłożenia tych samych treści. Nic nie pozostawia się tu domyślności odbiorcy, a wszelkie wnioski formułuje expressis verbis. Widać też staranie o dostosowanie egzemplów do prowadzonego wykładu, tak by jednoznacznie i bez wątpliwości dowodziły przedstawianych tez.

\section{Obrazowość}

Wśród stylistycznych dominant badanych tekstów ważna jest obrazowość, która również łączy się z celem dydaktycznym. Wykłady obficie ilustrowane są porównaniami i metaforami. Ludzkie zachowania, postawy, relacje najczęściej odnoszone są do świata zwierzęcego i roślinnego. W doborze członu porównującego wykorzystuje się doświadczenia wynikające z obserwacji natury czy hodowli zwierząt. Zdarzają się również porównania mitologiczne, „kościelne” (np. rodzice wobec dziecka są jak Pan Bóg czy Chrystus wobec ludzi [G Diij] ]), a nawet żeglarskie (częste $u$ Lorichiusa). Cecha uwydatniana przez porównanie albo jest wyrażona eksplicytnie, albo wymaga zrekonstruowania, co jednak na ogół nie nastręcza trudności, ponieważ porównanie najczęściej jest jednym z komponentów przeprowadzanego dowodu - taki sposób konstruowania porównań ma związek z dydaktycznym celem wykładu. Zwięzłe porównania, jak np.: Owa dziecię yeft by matpá, to co uyrzy to też ucżynić chce [G E $]$, są 
rzadsze, częściej comparatum (człon porównujący) przyjmuje formę rozbudowanego obrazu, jak w porównaniach homeryckich:

[...] iako ná drzewach ćienuchne zaifte gáłąski fnich wynikáiączą wielką okwitość iábłek, od początku afz do słufzney a ftałey ich wielkośći znafzaią, á tym ćzięzarem acż fię niepomału naginaią, awfzakoż fię żadną miarą nie łąmią: ktory cziężar gdy by fię z nienagła niemnożył, tedy by go mięfzfze á mocnieyfze gałęźi znośić niemogły, y nietylko by ty gałęźie odcżofnał, ale y podruzgał: także też y ludzie iefliżeby fię napierwey zdziecżinftwa, a potym przez wfzyftki lata, ku ćierpliwośći, y pracam tak umysłem iako y ćiałem nieprzyzwycżaili, tedy iefliżeby potym nieiaka trudność wrzecżách znagłá przipadła, tedy natychmiaft bywaią przełomięni, abowiem zadnego przećiwnego gwałtu nieumieią áni mogą znośić. [K M2-M2 $]$

Obrazy z życia zwierząt wykorzystywane są nie tylko w konstrukcji porównań, ale również jako egzempla $\mathrm{z}$ wzorami czy antywzorami zachowań, np.:

Obacżmy źwyerzętá co cżynyą zá fwym płodem, by też nyewyedzyeć yako przećiw drugiem fzturmowano y ná gardło im ftano, przedfię płodu nye opuffcżą, ná oftátek wolą płod wybáwić á sami wpásć, á yákoby ná myęsne yátki fie wydáć. Cżego lie dofić dofwyadflono, [a] poznáć łatwye z owce, źwyerżęcya [al]bo bydlęcyá bárzo pokornego, ći[che]go á boyáźliwego. To bydlę pokąt [nye] ma żadnego yágnyęcyá, fnadź y cyenyá fie fwego boi, ledá cżym tedy ye zapędzi y zaftrálfy, ále zás gdy fie okoći á yágnyę będzye myáłá, zá tym yágnyęcyem Imyáłosć taką weźmye, iż nikomu uftąpić nyechce, ná pfá, y ná infle drugye beftiye nogámi by cżym twárdem będzye tąpáyąc biłá, cżynyąc tho iż yáko ono mowyą, kożdemu fwego żal. [G Cviij, $-D$ ]

Efekt obrazowości daje też zastosowanie metafor:

Zá prawdę iáko trzeźwość ieft mátką wflyćkich cznot, thák záfyę piiáńftwo, wflyćkiego złego pocżątek. Piiańltwo ieft mylli cżłowiecżey flepotá. Nieprzyiaćiel cżyfthośći bo ią od káżdego odgania, á trzeźwość ieft, mylli cżłowiecżey, Imyflow, y cżłonkow wflyćkich ćielefnych opiekunká y ftroż, cżyftośći y wftydliwośći obroná y blifka przyiaćiołká [...]. [ [ L6 $\left.{ }_{\mathrm{v}}\right]$ 


\section{Erudycyjność}

Erudycyjność jako kategoria stylistyczna pozwala autorom postawić się w roli autorytetów. Takiej kreacji podmiotu mówiącego służy manifestowanie wiedzy, oczytania, znajomości historii starożytnej, a także oczywiście Biblii, ojców Kościoła (św. Augustyn [L L3 3, G Dv], św. Biernat [L L6 6 ]). O tym, że chodzi tu nie tylko o wymiar dydaktyczny, ale również o epatowanie erudycją, świadczą nagromadzenia egzemplifikacji ilustrujących tę samą tezę. Na przykład w dziele Lorichiusa, w rozdziale Człowiekowi przełożonemu náuká potrzebna ieft [L A5] znajdujemy wyliczenie znanych z historii osób, władców, którzy lubowali się w księgach:

[...] oni fthárzy pogáńfcy pánowie, ták fye pilno ucżyli, że fye bárzo naucżonemi á godnemi ku rofkázowániu ftáwáli. Iáko był Philip Mácedońlki krol [...]. Albo potym fyn iego Alexánder [...]. Káius Iulius Cefarz on Rzymfki [...]. Tyberius tefz Cefarz [...]. Dárius on możny Perfki krol [...]. Márek Antoni philofoph Cefarz [...]. Ale dla przedłużenia opuffczę Ieroná Syrákuzáńlkiego […]. Opuffczę tefz Attalum krolá Pergámfkiego, Magoná, Iubę krolá Mauritáńlkiego. Pompeiufa Rzymlkiego, Auguftufa, Tráianá, Antonium Pium, y inflych wiele ktorzy fye w dobrych náukách kocháli, y one będąc pány wielkiemi rozfferzáli. Iednegoż iefzcże muffę wfpomnieć Sygmuntá Cefarzá [...]. [L A5 $-\mathrm{A} 6]$

Nagromadzenie imion władców, którzy rozumieli korzyści płynące z nauki i propagowali ją wśród poddanych, nie tylko ma wartość dowodową, ale jest również środkiem nadającym wypowiedzi charakter erudycyjny. Dlatego wyliczeniem objęto też przykłady, z których rozwinięcia autor zrezygnował, dając jednak czytelnikowi sygnał, że zna ich więcej.

Zarówno powyższy fragment, jak i cytaty przytoczone poniżej pokazują, że dziedzictwo starożytności zostaje zaadaptowane do wykładu prowadzonego w duchu chrześcijańskim. Autorzy płynnie przechodzą od przykładów biblijnych do antycznych, np.:

Dla tegoć S. Páweł nápomina abyfmy fye winem w ktorym zbytek ieft nieopijáli. Y Plinius dla tego gáni ftátki abo kufliki ná ktorych czudzołofthwá wyryto $[\ldots] .\left[\mathrm{L} \mathrm{L6}{ }_{\mathrm{v}}\right]$

Weźmimy wzor á formę od pogánow, ktorzy nye znáyąc prawdziwego Bogá, záwfle zá dzyatki nowonarodzone nyeco ofiárowali bogom fwym, yako tho było u Rzymyánow [...]. W Atenach theż ten obycżay był [...]. Co theż piffą 
o Thezeufye, iż to był ucżynił, yechał do tego koscyołá, y oberznąwfly fobye przednye włoly, offyárował ony. Ten wzor ktory mamy álbo máyą rodzicy wybyeráć z obycżayu pogáńlkyego, ma záprawdę pochop y pobuthkę cżynić oycowi káżdemu z mátką, aby pánu Bogu [...] pilnye á z umyflu dzyękował [...]. [G Cvij-Cvij $]$

Źródłem jest jednak także mądrość ludowa zawarta w przysłowiach (wprowadzanych wyrażeniami typu jako mówia, pospolicie to mówia), np.: „Yáko pofpolicye mowyą, yáki pan táki kram, yáki ocyec táki fyn, nie dáleko záwfle od yábłoni pádnie yábłko” [G Ev], ,[...] czudzą rolą orzą, albo iáko mowią, Kozy miedzy czudzemi płonkámi á fzcżepy páfą” [L L4], „Pofpolićie to więc o bieśiádách mowią: śiedm' biefyádá, dziewięć zwádá” [L M5 ].

Nośnikiem erudycyjności są również szeregi synonimów. Występują one w badanych tekstach z dużą częstotliwością. Służą zamanifestowaniu językowej sprawności, leksykalnego potencjału, którym dysponuje autor. Najczęściej są to pary wyrazów rodzimych, np.: mgleli y truchleli [K O3], prze-

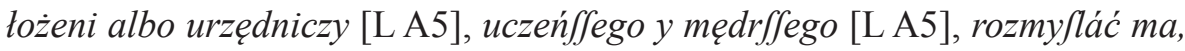
á Sobye rozbyeráć [ $\mathrm{G} \mathrm{D}_{\mathrm{v}}$ ], ftrzec fie y wyárowáć [G Dviij $\mathrm{v}_{\mathrm{v}}$ ], nye pfowat álbo nye zgorffyt [G E], ale też zapożyczonych, np.: ftátut á mándat [G Dviij], złáyat á sfukat [G E]. Frekwencję tego typu połączeń ilustruje następujący przykład: „Wcżym yeffcże pan Bog chuć á ferce nieyákye rodzicom przećiw płodu fwemu wlał á przydal, áby ták ono milowáli y flánowáli yáko kyedy fámi fiebye" [G Dij -Diij]. Są to synonimy kontekstowe, połączone spójnikami $i, a$ oraz albo. Obfitość zestawień tego typu w badanych tekstach oraz ich charakter (dominacja połączeń wyrazów rodzimych, z zakresu słownictwa ogólnego, o dużej frekwencji w XVI-wiecznej polszczyźnie) świadczą o tym, że nie służą one doprecyzowaniu znaczeń (trudno przyjąć, że znaczenie tak wielu wyrazów wymaga doprecyzowania przez wprowadzenie synonimu), ale stanowią wykładnik erudycyjności i retorycznych kompetencji autorów.

\section{Wnioski}

Zainteresowanie problematyką pedagogiczną w XVI wieku przyniósł humanizm. Z obliczeń Piotra Chmielowskiego wynika, że pomiędzy 1551 a 1560 rokiem ukazało się w Polsce „,blisko 30 wydawnictw pedagogicznych i dydaktycznych", przedruków i dzieł oryginalnych [Chmielowski 1877: 73]. Tematyka ta obecna była zresztą na polskim rynku drukarskim już w pierwszej połowie XVI wieku, jednak wyłącznie w publikacjach łacińskojęzycznych [Pawlak 1997a: XVIII-XIX]. Wśród renesansowych pisarzy zainteresowanych problematyką pedagogiczną wymienia się wybitnych przedstawicieli epoki: Andrzeja 
Frycza Modrzewskiego, Mikołaja Reja, Łukasza Górnickiego. Wybrane przez nas dzieła wyróżnia obecność w tytule słowa wychowanie. Zasługą Glicznera, Kwiatkowskiego i Koszutskiego jako tłumacza dzieła Lorichiusa było wyłożenie treści pedagogicznych po polsku. Czy ich osiągnięcie można zaliczyć w poczet zasług reformacji? Chmielowski w artykule Dziesięć lat z dziejów wychowania w Polsce XVI wieku, opublikowanym w 1877 roku na łamach „Bluszczu”, dowodził, że włączanie dzieł pedagogicznych do dorobku reformacji to przywłaszczanie „bezwarunkowo wszystkich szczegółów postępu ludzkości" [Chmielowski 1877: 65] $]^{8}$, jednak nie da się zaprzeczyć, że te dwa fakty, a więc polskojęzyczna twórczość o tematyce pedagogicznej oraz aktywność w środowisku reformacyjnym łączą się w biografiach omawianych autorów i chyba nie jest to przypadkowe. Kojarzenie reformacji z zainteresowaniami pedagogicznymi znamionuje zresztą nie tylko jej XIX-wiecznych sympatyków (zwłaszcza, jak sugeruje Chmielowski, germanofilów), ale także współczesnych wydawców. Na przykład edytor pism Marcina Kwiatkowskiego pisze we wstępie: „Pod wpływem reformacji duchowni kościołów luterańskiego i kalwińskiego rozpoczęli prace nad poradnikami dla rodziców w języku polskim” [Pawlak 1997a: XIX].

Przeprowadzona analiza, mająca postać rekonesansu badawczego, pokazuje, że autorom (wydawcom) chodziło o pozyskanie odbiorcy ponadwyznaniowego, a więc że dzieła swoje kierowali nie do współbraci w wierze, ale do szerzej zakreślonego kręgu społecznego. Dlatego nie ma w omawianych książkach pedagogicznych elementów polemiki wyznaniowej. Piotr Chmielowski w przywoływanym już artykule na temat dziejów wychowania w Polsce XVI wieku zwraca uwagę, że Gliczner w żaden sposób nie ujawnia swoich sympatii proreformacyjnych: ,[...] nie ma nie tylko żadnej cytaty z pism Lutra lub Kalwina, ale żadnego śladu idei protestanckich [...]. A kiedy mówi o kapłaństwie i małżeństwie, pisze zupełnie jak katolik uznający potrzebę bezżeństwa księży" [Chmielowski 1877: 114]. Taka postawa wynika z chęci nadania dziełom charakteru uniwersalnego, nieograniczonego wyznaniowo, natomiast zawężonego społecznie - co jest konsekwencją ówczesnych poglądów społecznych (sam Gliczner, zabiegając o porozumienie pomiędzy wyznaniami reformacyjnymi, wykluczał z tego kręgu radykalnych społecznie arian [Tazbir 1956: 167]). O nastawieniu na ponadwyznaniowego odbiorcę świadczą również dedykacje: Kwiatkowskiego dla Zygmunta Augusta, władcy katolickiego sympatyzują-

8 „Zwolenników reformacji pobudza do przyznania jej wielkiego znaczenia w dziejach pedagogiki jedynie chęć połączenia z jej nazwiskiem wszystkich, bezwarunkowo wszystkich szczegółów postępu ludzkości [...]" [Chmielowski 1877: 65]. 
cego z ideami protestanckimi [Meller 2016], Glicznera w Książkach o wychowaniu dzieci dla książąt słuckich Jerzego i Szymona, wyznających, zgodnie z rodzinną tradycją, prawosławie [Pawlak 1997b: 190] oraz w przekładzie ksiąg Lorichiusa dla Mikołaja Trzebuchowskiego, akolity Kościoła katolickiego [Kaczmarek 2016: 10].

Na poziomie stylistyczno-językowym XVI-wieczne „książki o wychowaniu dzieci" powstałe w kręgu reformacyjnym charakteryzuje dydaktyzm, z służebną wobec niego obrazowością, a także erudycyjność, która z kolei służy umocowaniu pozycji autora jako autorytetu. Dobór tekstów w naszym opracowaniu pozwolił również na ujawnienie innej, poza polskojęzycznością, cechy książek „o wychowaniu”, której związek z reformacyjnymi sympatiami autorów wydaje się prawdopodobny. Chodzi o obecność odwołań do Biblii, przywoływanie jako egzemplów wątków biblijnych w dziełach Lorichiusa i Glicznera, które powstały po wystąpieniu Lutra, a ich brak w rozprawce Kwiatkowskiego, będącej tłumaczeniem traktatu z początku XV wieku. Byłby to jeszcze jeden dowód szczególnej roli reformacji w popularyzowaniu Biblii.

\section{Bibliografia}

\section{Teksty źródlowe}

G - Erazm Gliczner, Kfyafzki o wychowányu dzyeći bárzo dobre, pożyteczne, y potrzebne, s których rodzicy ku wychowányu dzyeći fwych, náukę dotożna wyczerpnać moga. Teraz nowo uczynione y s pilnofcia wyrobione, Kraków 1558, http://www.dbc.wroc.pl/dlibra/doccontent?id=2579 [dostęp: 15 września 2017].

$\mathrm{K}$ - Marcin Kwiatkowski, Xiążecżki rofzkofzne á wielmi użytecżne o poććiwym wychowaniu y w rozmáitych wyzwolonich naukach cżwicżeniu Krolewskich, Xiążęcych, flacheczkich, y infzich ftanow dziatek, do Ubertina ná ten cżás Xiażęćia Padewskiego Łaczinskim iężykiem napifane. A teras z wielka pilnośćia á praca z Łaćińskiego na Polfki, przes MARCINA QWIATKOWSKIEGO Z ROZYCZ ná ten cżás X.J. M. Prufkiego, etc. etc. Iorgieltnika przetożone, y naktádem ubogim wydrukowáne. Roku Pańskiego. 1564, http://www.wbc.poznan.pl/dlibra/applet?mimetype$=$ image $\% 2$ Fx.djvu\&sec $=$ false \&handler $=$ djvu_html5\&content_url $=\% 2$ FContent\%2F301756\%2Fdirectory.djvu\&p=6 [dostęp: 15 września 2017].

L-Reinharda Lorichiufa kxięgi, o wychowaniu y o czwicżeniu káżdego przelożonego, nie tylko pánu ale y poddánemu każdemu ku cżytániu bárzo pożytecżne: teraz nowo z láćińfkiego ięzyká ná polfki przetożone, Kraków 1558, https://polona.pl/item/ 
reinharda-lorichiusa-kxiegi-o-wychowaniu-y-o-czwiczeniu-kazdego-przelozone go-nie-tylko,NTAwNjQ5NQ/4/\#item [dostęp: 15 września 2017].

\section{Literatura}

Barycz Henryk (1924), Dr Theodor Wotschke, Erasmus Gliczner. Ein Superintendent der grosspolnischen lutherischen Kirche, „Reformacja w Polsce”, t. 3, nr 11-12, s. 300-301.

Biblia brzeska (1563), Biblia fwięta, tho iest Kfieggi Stárego y Nowego Zakonu włafnie z Zydowskiego, Greckiego y Láćińskiego, nowo ná Polski ięzyk z pilnościa y wiernie wyłożone, Brześć Litewski, http://www.wbc.poznan.pl/dlibra/doccontent?id=2752 [dostęp: 15 grudnia 2017].

Biblia Leopolity (1561), Biblia To ieft Kxięgi Stharego y Nowego Zakonu ná Polfki ięzyk z pilnościa wedtug Łaćińfkiey Bibliey od Kośćiołá Krześćiáńfkiego powfechnégo przyięthey nowo wyłożona, Kraków, https://polona.pl/item/ biblia-to-iest-xiegi-starego-y-nowego-zakonu-na-polski-iezyk-z-pilnosciawedlug,MTE2MzMzOTU/2/\#item [dostęp: 15 grudnia 2017].

Bidlo Jaroslav (1977), Udział Jednoty Brackiej w walce o proces i egzekucję konfederacji warszawskiej, „Odrodzenie i Reformacja w Polsce”, t. 22, s. 159-175.

Chmielowski Piotr (1877), Dziesięć lat z dziejów wychowania w Polsce XVI wieku, „Bluszcz” t. 13, nr 9-11, 14-15, s. 65-67, 73-75, 81-82, 105-106, 113-114, http:// bcul.lib.uni.lodz.pl/publication/490 [dostęp: 16 października 2017].

Danysz Antoni (1912), Erazm Gliczner jako pedagog. Studium nad pierwsza pedagogika polska, „Roczniki Towarzystwa Przyjaciół Nauk Poznańskiego”, t. 38, s. 1-100, http://www.wbc.poznan.pl/dlibra/doccontent?id=119095 [dostęp: 22 lipca 2017].

Kaczmarek Krzysztof (2016), Duchowni ordynowani przez biskupa kujawskiego Jana Karnkowskiego w 1533 r., ,Roczniki Humanistyczne”, z. 2, s. 5-24.

Kraszewski Józef Ignacy (1842), Wilno: od początków jego do roku 1750, t. 4, nakładem i drukiem Józefa Zawadzkiego, Wilno.

Meller Katarzyna (2016), Listy do króla w sprawach wiary w polskich protestanckich Bibliach XVI i XVII wieku, „Poznańskie Studia Slawistyczne”, t. 10, s. 186-189.

Ottmann Rudolf (1886), Erazm Gliczner-Skrztuski. Przyczynki do życia i pism jego, „Przewodnik Naukowy i Literacki. Dodatek do Gazety Lwowskiej”, t. 14, nr 5, s. 440-451, http://www.wbc.poznan.pl/dlibra/doccontent?id=97679 [dostęp: 2 stycznia 2018].

Pawlak Marian (1997a), O autorze, w: Marcin Kwiatkowski, Edycje królewieckie 1564-1577, oprac., wstęp Marian Pawlak, Wydawnictwo Uczelniane WSP, Bydgoszcz, s. VII-XXXI. 
Pawlak Marian (1997b), Kilka uwag o pogladach pedagogicznych i o obowiazkach panujacych Reinholda Lorichiusa i Stanisława Koszutskiego, w: Szlakami przeszłości i czasów wspótczesnych, red. Kazimierz Puchowski, Józef Żerka, Wydawnictwo Uniwersytetu Gdańskiego, Gdańsk, s. 188-195.

Piskała Magdalena (2011), Filologiczna edukacja i szkolnictwo humanistyczne w XVI i XVII wieku w Polsce, w: Humanizm i filologia, red. Adam Karpiński, Wydawnictwo Neriton, Warszawa.

Pollak Roman, oprac. (1964), Nowy Korbut. Piśmiennictwo staropolskie: hasta osobowe $A-M$, Państwowy Instytut Wydawniczy, Warszawa.

Skubalanka Teresa (1997), Mickiewicz, Stowacki, Norwid. Studia nad językiem i stylem, Wydawnictwo Uniwersytetu Marii Curie-Skłodowskiej, Lublin.

Sławiński Wojciech (2003), Erazm Gliczner wobec Zgody Sandomierskiej. Przyczynek do biografii, „Czasy Nowożytne”, t. 15, s. 9-71.

Tazbir Janusz (1956), Walka z Braćmi Polskimi w dobie kontrreformacji, „Odrodzenie i Reformacja w Polsce", t. 1, s. 165-207.

Znajomski Artur (2015), Początki bibliografii lokalnej w Polsce. Józef Ignacy Kraszewski i jego bibliografia druków wileńskich, „Toruńskie Studia Bibliologiczne”, nr 2, s. 34-53.

Żołądź Dorota (1990), Ideaty edukacyjne doby staropolskiej. Stanowe modele i potrzeby edukacyjne szesnastego i siedemnastego wieku, Państwowe Wydawnictwo Naukowe, Warszawa-Poznań.

Ewa Woźniak, Magdalena Gozdek

\section{What language did the 16th century Reformation writers use to write about the upbringing of children (Gliczner, Kwiatkowski, Lorichius)?}

The article is devoted to stylistic properties of three pedagogical works that were published in Protestant circles in the 16th century Poland. The first one is the translation from Latin of the treatise written by German Protestant theologian Reinhard Lorichius titled Ksiegi o wychowaniu i o ćwiczeniu każdego przełożonego (1558), the second one is the Polish publication of Erazm Gliczner's Ksiażki o wychowaniu dzieci bardzo dobre, pozyteczne i potrzebne (1558) and the third one is the treatise written by the Italian humanist from the 14th and 15th century titled Ksiażeczki rozkoszne a wielmi użyteczne o poćciwym wychowaniu [...] dziatek (1564), translated by Marcin Kwiatkowski. The authors of the analysis recognised didacticism, vividness and erudition as the predominant stylistic features of discussed works. They proved that the 16th century books on upbringing of children had been addressed to readers of every denomination and lacked elements of religious polemics on the linguistic and stylistic level. The ideas 
of the Reformation can be connected mainly with popularization of the Bible, which was used as the source of exempla and sententiae in the works by Lorichius and Gliczner.

KeYwords: history of the Polish language (16th); historical stylistics; Reformation (16th); pedagogics; Erazm Gliczner; Marcin Kwiatkowski; Reinhard Lorichius.

dr hab. Ewa Woźniak, prof. nadzw. UL - Zakład Historii Języka Polskiego, Instytut Filologii Polskiej i Logopedii, Uniwersytet Łódzki; zainteresowania naukowe: historia języka polskiego, stylistyka historyczna, semantyka historyczna, terminologia prawna.

Magdalena Gozdek - studentka filologii polskiej, Uniwersytet Łódzki; zainteresowania naukowe: historia języka polskiego. 
